Het blijkt dat wanneer er geen constante kosten optreden

$$
\frac{\mathrm{K}}{\mathrm{P}}=\mathrm{AP}+\mathrm{B}+\frac{\mathrm{T}}{\mathrm{P}}
$$

overgaat in

$$
\frac{\mathrm{K}}{\mathrm{P}}=\mathrm{AP}+\mathrm{B}
$$

De gemiddelde kosten worden dan voorgesteld door een lineaire functie die uiteraard geen extreem vertoont. De voorwaarde voor de gelijkheid van de differentieele en integrale kosten is dus dan niet aanwezig.

De constante kosten spelen in dit geval dus een essentieele rol, alleen een geheel andere dan de schrijvers zich voorstellen.

Intusschen zal het den lezer niet moeilijk vallen om een curve te construeeren waar $\pi=\xi$ zonder dat er constante kosten optreden.

\title{
STATISTIEK EN BEDRIJFSSTATISTIEK
}

door Dr. J. H. van Zanten

Een boekje, dat de redactie mij ter recensie zond 1 ), geeft mij aanleiding hier nog eens - want het is niet de eerste maal - aandacht te vragen voor de verhouding tusschen de algemeene en wat men in den regel noemt de bedrijfsstatistiek en voor de wenschelijkheid eener veel nauwere samenwerking van die beide dan tot dusverre heeft bestaan.

Dit boekje acht ik n.l. een symptoom, een symptoom van wat ik de laatste jaren, nu ik in de gelegenheid ben geweest kennis te nemen van verschillende boekjes over statistiek, geschreven ten behoeve van hen. die eenig examen voor boekhouden, handel en administratie, handelskennis, accountancy, hebben af te leggen, meen te constateeren, n.l. het feit, dat zich een afzonderlijk vak statistiek voor het bedrijfsleven heeft ontwikkeld, dat naast de algemeene statistiek komt te staan, zooals deze door de statistische overheidsorganen wordt beoefend. Immers wat bij de lezing dier boekjes sterk opvalt, is, dat zij, hoewel zij - min of meer, hoewel meestal veel minder volledig - dezelfde onderwerpen behandelen als de algemeene handboeken over statistiek, dit doen op een wijze, alsof die zich in het bedrijf geheel anders voordoen dan elders, wat echter geenszins het geval is.

Deze opvatting heeft twee gevolgen, die beide even onnoodig en ongewenscht zijn, n.l. een scheiding, waar samenwerking noodig is, en een dubbele terminologie voor dezelfde begrippen.

Dat deze gevolgen onnoodig zijn, blijkt direct, als men nagaat, waaruit het statistisch onderzoek feitelijk bestaat. Dan vindt men, dat, op welk onderwerp het ook betrekking heeft, zij het de bevolking of het inkomen. de volkshuisvesting, het onderwijs of een tak van bedrijf dan wel een enkele onderneming, steeds denzelfden gang heeft, mits men ervan uitgaat - en dat zal iedereen doen, die er zich mee bezig houdt, omdat statistiek nu eenmaal niet anders is - dat statistiek toch altijd het vak blijft, dat ten doel heeft massa's waar te nemen en daarin verschijnselen te zoeken, die men op andere wijze niet kan vinden; dat zij dus eenerzijds is de wetenschap, die leert, hoe men dat doen moet, anderzijds de prak-

1) W. Westra, Inleiding tot de bedrijfsstatistiek.

m a b blz. 384 
tijk der uitvoering dier waarneming, waarin men zich oefenen en bekwamen kan. In den regel neemt men aan, dat het gebruik maken van de door de waarneming verkregen gegevens, het bepalen van de beteekenis van en het werken met de gevonden verschijnselen niet tot de statistiek behoort, maar tot het vak, ten behoeve waarvan zij heeft gewerkt.

Elk statistisch onderzoek is dus gericht op het vinden van verschijnselen en kan met het oog hierop in drie phasen worden gesplitst:

a. die van de bestudeering, hoe de waarneming moet geschieden; zij omvat: 1e. vaststelling van wat men wil onderzoeken; voor de onderneming is dat b.v. den invloed van reclame of van het seizoen op den omzet; de productiviteit van den arbeid, enz.; $2 e$. vaststelling van de gegevens, die het onderzoek zal moeten opleveren, en van wat men moet doen om ze te krijgen; daarbij moet men in het bijzonder ervoor zorgen, dat de gegevens vergelijkbaar zijn met de bij een vorig onderzoek en bij de onderzoeken van anderen verworven gegevens; deze vergelijkbaarheid is een der voornaamste zorgen der statistiek, omdat zonder haar geen verschijnselen worden gevonden; men bereikt haar door goede definities van de onderwerpen van het onderzoek; $3 e$. vaststelling van instructies voor het personeel, ontwerpen van formulieren, telkaarten, enz., aanschaffen of geschikt maken van machines en derg.; en $4 \mathrm{e}$. maken van een begrooting van kosten, bepaling en keuze van het benoodigde personeel. aanschaffing van het materiaal en alles wat verder ter voorbereiding noodig is;

b. die van de uitvoering der waarneming, welke omvat: 1e. het leiden van het onderzoek, het bevorderen van uniformiteit van handelen, als er verschillende personen mee zijn belast, en het oplossen van moeilijkheden daarbij, de contrōle en het toezicht; $2 \mathrm{e}$. de verzameling en de contrôle van het materiaal ( $n$ l. de ingevulde formulieren, telkaarten en derg.), de groepeering en de telling; het is natuurlijk mogelijk, dat dit geen afzonderlijk werk is, doch samenvalt met het overige administratieve werk der zaak; dan is echter toch een speciale instructie noodig; het is ook mogelijk, dat de statistiek gebruik maakt van reeds van zelf in de zaak ontstane cijfers; dan vervalt de geheele afzonderlijke verzameling natuurlijk; $3 e$. de vaststelling der eindresultaten;

c. die van het verwerken van het resultaat, omvattende: 1e. het vaststellen der verschijnselen, waarbij tegenwoordig veel gebruik wordt gemakkt van de methoden der wiskundige statistiek; hier ligt dus de taak van den wiskundig onderlegden statisticus, waarmede niet gezegd wil zijn, dat dit onderdeel een aparten man behoeft, alleen dat de wiskundige statisticus geen volledig statisticus is, als hij ook het onder a. en b. genoemde niet kent; $2 e$. het vergelijken van de resultaten van het onderzoek met die van andere onderzoekingen, voor de onderneming dus het vergelijken van wat daar of in een onderdeel daarvan gevonden is met wat bij andere ondernemingen of andere onderdeelen is gebleken en ook met algemeene statistische gegevens, zooals de bevolking, het nationaal inkomen, enz. (wat men noemt externe statistiek, in tegenstelling met het eerstgenoemde, de interne), en waarvoor de statisticus bekend moet zijn eigenlijk met het geheele gebied der statistiek. Hierbij komt men zeer licht buiten de eigenlijke statistiek terecht. Op dit terrein wordt dikwijls van statistiek gesproken, terwijl het dat niet is; éen enkel willekeurig gekozen voorbeeld hiervan: een gemiddeld bruto-winstpercentage, den maandelijkschen goederenvoorraad, den statistischen eindvoorraad vast te stellen, behoort tot de taak der statistiek, maar niet om op grond der 
statistische gegevens de winst vast te stellen of correcties in de boekhouding aan te brengen.

Opzettelijk hebben wij in dit overzicht telkens voorbeelden gegeven uit het bedrijf, maar het spreekt van zelf, dat men dat voor elk veld van statistisch onderzoek kan doen. Zoo kan men sub a., le, in plaats van den invoed van de reclame op den omzet, noemen: bij de bevolkingsstatistiek den invoed van het weer op de sterfte, bij de inkomensstatistiek de verdeeling van het nationaal inkomen, bij de onderwijsstatistiek de wijze, waarop de H.B.S. wordt doorloopen, en zoo zou men kunnen voortgaan. Reeds hieruit volgt, dat hij, die in de onderneming de statistiek wil beofenen, op de hoogte moet zijn van de methode in het algemeen, die hij dan - trouwens zooals elke statisticus - moet toepassen op het speciale onderwerp, waarop hij zich richt.

En dit is nog om een andere reden noodig. Wij spreken n.l. aldoor over ,,bedrijfsstatistiek", maar deze omvat zeer duidelijk twee gebieden, n.1. de tot de sociaal-economische statistiek behoorende statistiek van het bedrijf of liever de verschillende bedrijfstakken als complexen der ondernemingen, die gericht zijn op hetzefde product, en de bedrijfseconomische statistiek in de enkele onderneming. Het staat vast, dat de eerstgenoemde behoort tot de algemeene statistiek en niet door de onderneming wordt beoefend; de ondernemingsstatistiek kan alleen van haar een nuttig gebruik maken voor het zoeken van verschijnselen.

Voor de boekjes nu, waarover wij spraken, komt het eigenlijk slechts op behandeling der ondernemingsstatistiek aan en feitelijk slechts op de interne. Ik wijs hierop speciaal om nog eens duidelijk te laten uitkomen. welk een betrekkelijk klein onderdeel der statistiek in het algemeen ten slotte de ondernemingsstatistiek, waarover het hier loopt, toch eigenlijk is, een onderdeel, dat geheel op dezelfde lijn staat als de andere bijzondere onderwerpen der statistiek, zooals, om ons tot de groote groepen te bepalen, de bevolkings-, de economische, de sociale, de medische statistiek, enz. Als zoodanig verdient de ondernemingsstatistiek natuurlijk ten volle de beoefening door speciaal opgeleiden, maar dat is bij de andere onderwerpen niet anders; de sociale statistiek zal men bij voorkeur door sociografen, de medische door medici, de onderwijsstatistiek door onderwijsdeskundigen laten leiden, maar dat zal dan toch altijd geschieden in het raam der algemeene statistiek, waarbuiten de ondernemingsstatisticus evenmin valt als de anderen.

$\mathrm{Na}$ deze uiteenzetting zal het den lezer wel duidelijk zijn geworden. wat ik bedoeld heb met de onnoodige en ongewenschte gevolgen van een wijze van onderricht in de ondernemingsstatistiek, waarbij het den leerling wordt voorgesteld, alsof die iets geheel aparts is met eigen middelen en eigen terminologie.

In de eerste plaats leidt dit tot het gevolg, dat zij, die de statistiek uitsluitend op deze wijze hebben geleerd, onbekend blijven met het feit, dat de statistiek een vak is met een geschiedenis van eenige eeuwen, hetwelk tal van beoefenaren heeft gehad en nog heeft, onder wie er zijn, die wereldberoemd zijn geworden; een vak, dat beoefend wordt in nationale studiekringen of vereenigingen en in bijna 100 jaar oude internationale bijeenkomsten, waar de regels van het vak besproken en vastgesteld worden; dat ten slotte elk land een uitgebreide staats- en gemeente-organisatie bezit, waaraan tonnen gouds ten koste worden gelegd. In den regel wordt daarvan in de bedoelde boekjes niets vermeld.

m a b blz. 386 
Voor zoover nu de studie in statistiek slechts is bestemd om de noodige kennis te verkrijgen voor het vervullen van ondergeschikte functies in het bedrijfsleven, voor hen, die het niet verder brengen dan meewerken aan het uitvoeren van statistisch onderzoek volgens de aanwijzing van leiders, is het niet zóó erg, als zij niet meer van statistiek hebben geleerd 2). Maar indien de statistische studie dient als hulpmiddel hetzij voor de wetenschappelijke bedrijfsvoering hetzij voor een wetenschappelijke bedrijfscontrôle, dan kan men gerust zeggen, dat een beperking der studie tot die boekjes haar nog steeds niet losmakt van de vroegere methode van studeeren in het boekhouden, die bestond in het van buiten leeren van feiten en regels zonder wetenschappelijke fundeering. Zoodra men erkent, dat het hier gaat om een wetenschappelijke opleiding, ook buiten de universitaire, d.i. om een vorm van studie, waarbij het te doen is om kennis van ontstaan, ontwikkeling en causaliteit van de dingen. dan mag men - om ons tot de statistiek te bepalen - den leerling niet geven een onderdeeltje van een groot, sedert eeuwen ontwikkeld gebied en het voorstellen, alsof dat onderdeeltje het vak is, dan moet men dat zetten in het kader, waarin het behoort, n.l, in dat van een algemeen vak, beoefend door velerlei vakmenschen, van welks resultaten men profiteeren kan en moet en aan welks resultaten men omgekeerd zijn eigen speciale kennis en ervaring ten goede kan en moet laten komen.

Dit brengt mij tot een tweede onwenschelijkheid van het apart blijven, n.1. dat men den studeerenden aldus de gelegenheid onthoudt om, als zij eenmaal beoefenaren van het vak zijn geworden, samen te werken met de andere beoefenaren op de overige gebieden van onderzoek, deel te nemen aan hun bijenkomsten en invloed te oefenen op hun werk, opdat ook met de behoeften van hun onderdeel wordt rekening gehouden bij de bestudeering der zich voordoende kwesties, de vaststelling van regels, de uitbreiding der terminologie, de schepping van nieuwe methoden, en omgekeerd ook de anderen in staat te stellen hunnerzijds te profiteeren van resultaten, die op hun gebied zijn verkregen. Men bedenke ook, hoe nuttig het kan zijn voor de externe statistiek in de onderneming, als de statisticus geregeld voeling houdt met collega's en daardoor weet, welke gegevens er zijn en tot wie hij zich kan wenden, als hij ze noodig heeft.

Gelukkig ontbreekt die samenwerking niet geheel; de ontwikkeling der bedrijfsstatistiek heeft als van zelf daartoe geleid. Wij wijzen slechts eenerzijds op het streven van instituten als het Economisch Instituut voor den Middenstand, de Bedrijfsstudiegroep voor marktanalyse en conjunctuuronderzoek van het Ned. Instituut voor Efficiency, de Ned. Studiecommissie voor verkoopsorganisatie, die voldoende bekend zijn, anderzijds op de medewerking, die het Centraal Bureau voor de Statistiek aan vele ondernemingen vraagt voor de samenstelling van omzet- en distributiekostenstatistieken. Ook de Nederlandsche. Statistische Studiekring, waarvan prof. Methorst voorzitter is en die in den winter elke maand een bijeenkomst met een wetenschappelijke inleiding houdt, telt eenige bedrijfsstatistici. Maar wederom, in de bedoelde boekjes leest men van dat alles niets en zoo ontstaat de mogelijkheid, dat er met wetenschappelijke bedrijfsvoering of - contrôle belasten worden gevormd, die van dat yeheele gebied nooit iets hebben vernomen.

Voegt men dan nog hierbij, dat deze menschen ook een afzonderlijke

2) Indien het althans bruikbare boekjes $z \mathrm{ijn}$; ik ken er, uit welker naïeveteit men onmiddellijk ziet. dat de schrijver feitelijk van statistiek nagenoeg niets weet. 
terminologie hebben geleerd, waardoor zij allerlei begrippen, waarmede de andere statistici evenzeer werken, anders noemen dan zij, zoodat de twee categorieën elkaar niet eens verstaan, als zij over het vak spreken, dan zal men moeten toegeven, dat deze toestand niet alleen ongewenscht ss, maar ook geenszins noodig.

Zoo komen wij tot de conclusie, dat allen, die het welmeenen met de op statistiek gebaseerde wetenschappelijke bedrijfsvoering en contrōle, de statistiek in haar volle algemeene waarde behooren te erkennen. De academisch gevormde accountants en bedrijfsleiders, die aan hun universiteit of hoogeschool immers de statistiek hebben geleerd van hoogleeraren of lectoren, die over het algemeen geen speciale bedrijfsstatistici zijn, hebben hier, dunkt ons, een taak, n.l. hun collega's in die richting te bewerken. Het best kan dat geschieden door te bevorderen, dat bij de verschillende examens kennis van de algemeene statistiek als eisch wordt gesteld; daardoor zullen van zelf de boeken, die bij de opleiding voor de studie worden gebruikt, meer algemeen georiënteerd worden. Zij zullen daartoe zooals gebruikelijk is, in twee deelen dienen te worden gesplitst: een algemeen deel, waarin iets over oorsprong, ontwikkeling en tegenwoordigen stand van het vak en iets over de organisatie van de algemeene statistiek wordt meegedeeld en verder alle kwesties, die een algemeen karakter dragen, worden behandeld, en een speciaal deel, waarin de toepassing van een en ander op het bedrijf en de onderneming wordt gegeven. Het is onze overtuiging, dat daardoor de studie van het vak slechts weinig zal worden verzwaard; die geringe verzwaring lijkt ons echter wel zeer noodig.

Als op deze wijze het bedrijfsleven zich meer rekenschap gaat geven van de beteekenis der algemeene statistiek en meer voorlichting en aansluiting bij haar gaat zoeken, en de overheidsstatistiek van haar kant nog meer dan tot dusver aan dit streven tegemoetkomt, kan dat niet anders dan tot een wederzijdsche verrijking leiden, die het vak uitermate ten goede zal komen. Moge dit opstel een steentje daartoe bijdragen.

\title{
VERGELIJKING WET OP DE INKOMSTENBELASTING 1914 EN BESLUIT OP DE INKOMSTENBELASTING 1941
}

\author{
door C. L. Vervaeck
}

Op 31 December 1940 behoort de Wet op de Inkomstenbelasting 1914 tot het verleden en treedt daarvoor in de plaats het bovengenoemde besluit. Het ligt in mijn bedoeling in dit artikel enkele van de voornaamste verschillen tusschen het oude en nieuwe stelsel van heffing eener Inkomstenbelasting te behandelen.

De subjectieve belastingplicht is in Hoofdstuk I van het Besluit 1914 behandeld. Welke natuurlijke personen, die niet binnen het Rijk wonen, hier te lande belastingplichtig zijn wordt uiteengezet in art. 39 .

Bij vergelijking met de oude wet blijken er drie belangrijke verschilpunten:

a. De stichtingen, die een bedrijf of beroep uitoefenen, zijn niet meer in het Besluit genoemd. Het is de bedoeling deze kleine groep onder de Winstbelasting te laten vallen.

m a b blz. 388 